\title{
Chapter 12 \\ Environmental Citizenship in the Context of Primary Non-formal Education
}

\author{
Jelle Boeve-de Pauw and Rares Halbac-Zamfir
}

\subsection{Features of the Primary Educational Sector}

Kellert (2005) identifies three basic stages for children's development of environmental values and actions. Each stage is associated with a specific approach to environmental education (Kellert 2005): (1) Early childhood (ages 3-7), sometimes labelled pre-primary education; (2) early/middle grade school (ages 7-11), also labelled primary education; and (3) adolescence (ages 12-18), labelled secondary education. The cognitive abilities and psychological development of children at these different stages are very diverse. In this chapter we focus on non-formal education for children in the primary ages. Primary education is the second link in most of the formal education systems, and it shares several basic characteristics across the systems. First, it provides basic training, instrumental component of general culture, and second it aims at the development of human personality components: intelligence, curiosity, skills and moral habits, etc. These two features essentialise the main functions of education for children between the developmental ages of 6 and 12 years old. First, there is the function of achieving basic education by lowering the age of retraining and including it in a system of organised and coordinated education in scientific humanities. Second, there is its function of developing the personality of the child and respecting their own capacities, which implies both the individualisation of education and the promotion of formative education (or Bildung; Biesta 2015).

\footnotetext{
J. Boeve-de Pauw ( $\triangle)$

Department of Training and Education Sciences, Research Unit Edubron, University of Antwerp, Antwerp, Belgium

e-mail: jelle.boevedepauw@uantwerp.be

R. Halbac-Zamfir

Department of Hydrotechnical Engineering, Polytechnic University of Timisoara,

Timişoara, Romania
} 
Reformations of early and primary education based on the Geneva Declaration of the Rights of the Child (UNICEF 1990) have led to redefining the goals that it pursues. We mention below those we see as being relevant discussion points in relation to Education for Environmental Citizenship.

1. Primary education should foster a free, complete and harmonious development of the child's personality according to its own pace and needs and support its autonomous and creative learning and development.

2. Primary education should develop the ability of children to interact with other children, adults and the environment, and to acquire new knowledge, skills, attitudes and behaviours. It also needs to encourage explorations, exercises, trials and experiments, all as autonomous learning experiences.

3. Primary education should contribute to each child's discovery of its own identity, autonomy and the development of positive self-image and support the child in the acquisition of the knowledge, skills, habits and attitudes necessary for them to enter school and lifelong learning.

As we will debate later in this chapter, non-formal education presents a unique educational context in which children's environmental identities (see, e.g. Clayton 2003) can be developed and where they can acquire the competences needed to become Environmental Citizens.

\subsection{Non-formal Education for Environmental Citizenship}

\subsubsection{Defining Non-formal Education}

Our aim in this chapter is to explore how non-formal education can take place for young children as a space to experiment with and learn the competences needed to become an Environmental Citizen. Before doing so, it is only fair that we explain how we interpret the term 'non-formal education'. In line with Norland (2005), we acknowledge that "any term beginning with "non" can be perceived as somewhat negative or even disagreeable: non-communicative, non-responsive, non-productive' (p. 6). Non-formal education should not be perceived as the lack of something, but rather as an educational context with unique qualities. The concept emerged in the international discourse on education about 40 years ago. It is associated with the idea of lifelong learning and emphasises the importance of education going beyond the formal frameworks of the education system, whether in educational spaces other than school, or through education activities that are not subject to the school curriculum but that respond to the needs and interests of a group's knowledge and development.

The value of non-formal education arises because the formal education system is adapting too slowly to the socio-economic and cultural changes of the world in which we live. Non-formal education is different from formal education, both in 
content and through forms of achievement. Course content is organised within areas of interest (not years of study or academic subjects) and is very diverse in terms of duration, organisation or teaching. Non-formal education can be characterised by concrete responses to fixed requirements, clearly defined interests, obtaining abstractions by extracting knowledge from practical life, minimising teaching functions, and leaving more room for learning. Non-formal could as such be defined as the absence of something formal, and non-formal education could then be interpreted as the absence of formal education. We argue that the absences of the frameworks and structures of formal education are strengths of non-formal education, especially when it comes to Education for Environmental Citizenship. Indeed, non-formal learning provides an opportunity for education to rely on the natural process of learning, by allowing it to be active, volitional and internally mediated (Heimlich 1993).

In line with Norland (2005), we contrast dimensions of education in the formal and non-formal sphere in Table 12.1.

\subsubsection{Non-formal Primary Education and Environmental Citizenship}

Fordham (1993) points out that, in the case of non-formal education, organisation and learning planning should be assumed by the learners themselves; as such, a 'bottom up' approach is necessary in order to give learners the ability to understand or not to change the surrounding social structures. This participatory principle, which underpins the non-formal philosophy, should be understood as participation in self-training (understanding needs and finding appropriate training solutions in the respective fields) and in the life of the community/society. Moreover, in the case of non-formal education, it should be negotiated by the trainees group so as to respond to their needs as best as possible. One of the specific directions of nonformal education is to support the population for more rational use of natural resources.

Table 12.1 Characteristics of formal and non-formal education programmes

\begin{tabular}{l|l|l}
\hline Dimension & Formal & Non-formal \\
\hline Focus & Emphasis on teaching & Emphasis on learning \\
\hline Curriculum & Sequential prescribed curriculum & $\begin{array}{l}\text { Variety and flexibility, often } \\
\text { determined by the learners }\end{array}$ \\
\hline Relationships & Teacher-student, often hierarchical & $\begin{array}{l}\text { Facilitator-learner, often informal } \\
\text { relationships }\end{array}$ \\
\hline $\begin{array}{l}\text { Time } \\
\text { orientation }\end{array}$ & $\begin{array}{l}\text { Often originate at (member) state level. } \\
\text { Typically high costs }\end{array}$ & $\begin{array}{l}\text { Often local and limited. Typically } \\
\text { low costs }\end{array}$ \\
\hline Structure & High structure typically required & Immediate \\
\hline
\end{tabular}


The extent to which these principles also hold for (young) children is subject to debate and research, but there is some evidence that allowing children to co-decide on what on how they learn about and for sustainability, has a direct impact on their sustainability consciousness (Boeve-de Pauw et al. 2015). As such, participatory learning for children in primary schools seems to contribute to the development of competences that pave the way for them to develop into Environmental Citizens. It should be noted that in their study, Boeve-de Pauw et al. (2015) also showed that students in secondary education had increased participation in their own learning process (which meant an increase in learning sustainability learning outcomes), but for students in primary education (grade 6 in particular), there seemed to be a point of too much participation, resulting in a decline in the learning outcomes. The authors identified 'that learning environments with (among others) very high degrees of participation in the learning process might be too demanding, cognitively complex, or contain to high degrees of novelty for sixth graders [...], which could explain the resulting drop in the [educational] effectiveness [promoting their adoption of sustainability related actions]' (p. 15710).

We should acknowledge that these results stem from research in the context of formal education. This is especially relevant when we consider Environmental Citizenship as an outcome of non-formal education. Younnis (2011) highlights that extra-curricular activities are essential in encouraging civic identity and action. Given the focus of Environmental Citizens on 'responsible pro-environmental behaviour of citizens who act and participate in society as agents of change in the private and public sphere, on a local, national and global scale, through individual and collective actions, in the direction of solving contemporary environmental problems, preventing the creation of new environmental problems, achieving sustainability as well as developing a healthy relationship with nature' (Hadjichambis \& Reis 2018). We therefore use the term non-formal Education for Environmental Citizenship as an education that occurs outside the classroom, e.g. in after school programmes, community-based organisations, museums, zoos, visitors centres, libraries and at home, and which contributes to learning specific or all competences needed as an Environmental Citizen.

We also highlight four relevant characteristics that can help define non-formal programmes in the realm of Education for Environmental Citizenship. Each of these characteristics offers opportunities that can benefit the goals of Education for Environmental Citizenship. We also focus on the development of a healthy relationship with nature.

1. The purposes of the programmes are not always uniformly or solely educational. Providers of such programmes may also embed goals that are non-educational but social or recreational.

2. The target audiences are diverse and can include school classes, other groups, families and walk-in visitors. Participants in non-formal environmental learning programmes are not often well known, and it can be difficult to describe the audiences in ways to facilitate programme development specifically for the target audience. 
3. The duration of learners' participation or exposure to the programmes varies widely. It can range from a visit of about $2 \mathrm{~h}$ to full day or residential programmes where learners sleep over at environmental sites and engage in non-formal learning for up to a week or more.

4. Non-formal education programmes are typically developed and offered by organisations other than traditional education institutions. Often the programme is developed collaboratively between multiple organisations from the public, non-profit and private sectors.

In conclusion, non-formal learning occurs in a planned but highly adaptable manner in institutions, organisations and situations beyond the sphere of formal education. It shares the characteristic of being mediated with formal education, but the motivation for learning may be wholly intrinsic to the learner (Eshach 2007). For the development of Environmental Citizenship, non-formal education is highly relevant given its potential to prompt the learning of skills, knowledge and other outcomes in addition to formal learning (Lockhart 2016). It also provides the flexibility to adapt to rapidly changing expectations and societal needs. For these reasons we agree with Romi and Schmida (2008) in labelling non-formal education as a major educational force and highlighting its added potential on top for formal Education for Environmental Citizenship. Examples for programmes that offer nonformal education for environmental citizenship and have been studied empirically are the US Earthkeepers programme (also implemented and in, e.g. Cyprus; Van Marte and Johnson 1988; Manoli et al. 2014), environmental museum visits (e.g. at the Natural History museum; Kimble 2014), place-based environmental programmes (e.g. in the Czech Republic, Cincera et al. 2014), educational visits natural areas (e.g. the educational programmes by the Province of Antwerp in Flanders, Belgium; Boeve-de Pauw et al. 2019), extra-curricular forestry education (e.g. in Mexico; Ruiz-Mallen et al. 2009), etc.

\subsection{Children Can Learn to Become Environmental Citizens}

\subsubsection{Children Are Not Adults}

A problem that might occur in non-formal environmental education programmes that target children in primary education is that they approach education and citizenship competences from the perspective of an adult, rather than from that of a child. Education for Environmental Citizenship should, especially for children of primary school ages, treat children as children and not as adults. Furthermore, EEC should attune itself to appropriate levels of abstraction in teaching and learning. Teaching children about nature abstractly in the classroom does not lead to proenvironmental behaviours in later life (Schultz 2000). Teaching abstract concepts like habitat destruction, acid rain, holes in the ozone layer and whale hunting to 
young children can even lead to dissociation from nature and premature abstraction (e.g. White and Stoecklin 2008; Ausubel 1964).

Hayward (2012) states that 'as educators, parents and policy makers, we need to pay closer attention to complex interactions of the micro- and macro-level changes taking place in a child's environment [...] we rarely take the complex ecological reality of a child's world seriously' (p. 3). Children's ecological reality is a complex series of nested interactive systems providing daily dynamic experiences with diverse impacts at the micro and macro level of their lives and their surrounding environment. These experiences are generally approached within a scientific framework (environmental sciences), without considering primary education level features and the need to translate the results of these experiences at a level easily understood by children. The language of environmental sciences has not yet been adapted to a primary education level, missing the fluidity so characteristic for this age.

When we present children with problems beyond their cognitive abilities, understanding and control, they can 'become anxious, tune out and might develop a phobia to the issues. In the case of environmental issues, biophobia-a fear of the natural world and ecological problems - a fear of just being outside - can develop' (White and Stoecklin 2008; Barbiero and Marconato 2016). These principles should be taken into account by the Education for Environmental Citizenship since it aims to foster environmental agency in children through teaching and learning for Environmental Citizenship. Studies on the loss of rainforests and endangered species may be perfectly appropriate for adolescent or older children, but it is developmentally inappropriate for younger children (Wilson 1993; Kellert 2002). We also need to be aware that the citizenship aspect of EEC, which includes a strong call for action to contribute to solving major complex issues, is cognitively too demanding for children under 12 years old. Messages for action as well as the problems they intend to solve need to designed or appropriated to the abilities and needs of children. Furthermore, teaching children by using virtual nature or exotic places that are by definition not part of their real life experiences can result in them developing a conception of nature that diminishes the value of their own local natural environments. As such, this reduces their potential to develop an internalised call to protect those areas (see, e.g. Levi and Kocher 1999), or to develop Environmental Citizenship based on their experiences with action for their own local (natural) environment.

\subsubsection{Social Practice Theory and the Formation of an Environmental Identity}

Social practice theory suggests that people develop their identities in different facets of their lives, as they respond to their environment and adopt the practices (and as such possibly also the environmental actions) of others around them (Williams and 
Chawla 2016). One of these facets of identity development is what Kempton and Holland (2003) term a 'social environmental identity': people's self-definition relative to an environmental reference group. This could be a general identity such as 'environmentalist' or a membership to an environmental group. The goal of Education for Environmental Citizenship is to 'cultivate a coherent and adequate body of knowledge as well as the necessary skills, values, attitudes and competences that an Environmental Citizen should be equipped with in order to be able to act and participate in society as an agent of change [...] in the direction of solving contemporary environmental problems, preventing the creation of new environmental problems, in achieving sustainability as well as developing a healthy relationship with nature' (Hadjichambis \& Reis 2018). People are not likely to take action for the environment unless they incorporate improving their environment (and the natural environment) into their identity (Tesch and Kempton 2004).

As identified above, non-formal education from the ages of 6-12 years old holds great potential in supporting and building such an identity. According to social practice theory, people build their identities in the course of action, i.e. while performing and living actions, and from experiencing the impact of those actions on their environment as well as on themselves. Therefore, researchers in social practice theory look for pivotal moments in people's identity formation across their entire lifespan. As people's sense of self as agents of change (Hadjichambis \& Reis 2018) grows, three specific changes occur which should be taken into account when designing educational interventions that connect to EEC:

1. There is an increasing salience to the natural world by becoming more attentive and knowledgeable, and being more aware of environmental problems.

2. There is growing identification with the world of environmental action, by acquiring a sense of agency for taking responsibility for action, and caring about the consequences of one's own actions.

3. People would gain knowledge through action; people can learn about practical activities associated with environmental action and become acquainted with a strategic network of other actors.

Thomashow (1995) defines an ecological identity as 'all the different ways people construe themselves in relationship to the earth as manifested in personality, values, actions, and sense of self'. He notes that 'The interpretation of life experience transcends social and cultural interactions. It also includes a person's connection to the earth, perception of the ecosystem, and direct experience of nature' (p. 3). Similarly, Clayton (2003) defines an environmental identity as 'one part of the way in which people form their self-concept: a sense of connection to some part of the nonhuman natural environment, based on history, emotional attachment, and/or similarity, that affects the way in which we perceive and act toward the world' (p. 45-46).

Clayton (2003) also states that environmental identity is a strong motivating force for individuals to act in ways that protect the environment. In turn their identities will guide social, political and personal behaviours such as those actions identified in the definition of Environmental Citizenship (Hadjichambis \& Reis 2018). 
According to self-determination theory (Ryan and Deci 2003), identities serve 'basic needs' including a sense of belonging, sense of competence and autonomy. Identities become strong when they meet these important needs. Although the questions concerning identity may become central during adolescence, social practice theory puts that people begin to learn what society expects of them already in early childhood, and as such children already develop personal responses to those expectations. Social Practice Theory merges a personal identity that involves personal goals, values and beliefs with a cultural identity or sense of belonging to a social and cultural group (Williams and Chawla 2016), and identifies middle childhood as an essential phase in the development of such identity. It is therefore very relevant to explore what kind of experiences can contribute to the formation of an environmental or ecological identity during this phase in human development. These experiences can be used to foster Environmental Citizenship through targeted non-formal EEC.

\subsubsection{Significant Life Experiences That Contribute to the Formation of an Environmental Identity}

Research concerning significant life experiences aims to uncover which events in one's history have been so impactful that they are experienced as pivotal in the formation of their motivation to act for the environment and can as such be described as defining moments in the formation of Environmental Citizenship. This line of research has a long tradition (Tanner 1980) and consistently shows that participants across the globe attribute their commitment to environmental action to a common set of experiences. They span spending time outdoors and experiencing nature during (early) childhood, the influence of parents and other family members, influential teachers at school, active involvement in community life, reading eyeopening books or seeing documentaries and experiencing the loss or degradation of nature in the vicinity of one's personal life (Chawla 2009).

Numerous studies have shown that non-formal learning experiences in nature during childhood are ranked among the most powerful and significant life experiences. Children's experiences during (early) childhood nurture the conception of the child as a part of nature, of including nature in its conception of the self (Cheng and Monroe 2012) and the development of an environmental identity. It is during childhood when children's experiences give form to the values, attitudes and basic orientation toward the world that they will carry with them throughout their lives (e.g. Kahn 2002). Regular positive interactions with nature allow children under 12 years old to feel comfortable, develop empathy and grow to love it (e.g. Gill 2014). Cheng and Monroe (2012) identify several key elements associated with children's connection to nature: enjoyment of nature, empathy for creatures, sense of oneness and sense of responsibility. This last factor includes children's notions of the impact of their own actions on the natural environment and their rights and 
duties to protect nature and is as such closely connected to the ENEC definition of Environmental Citizenship.

In significant life experiences research, formal education is consistently ranked high but lower than non-formal education. Also the social context with which these experiences occur is important. Participants often report that their own commitment to act for the environment has sprouted from inspirational role model in their families or peer groups. Thanks to their flexibility in organisation and intended outcomes, non-formal education programmes can be considered as promising. With these programmes, young children and preadolescents can develop into role models for Environmental Citizenship and inspire their peers. In their study on the environmental literacy of youth movement members, Goldman et al. (2015) show how self-perception as role models for younger members on environmental actions is part of their social activism. Inspiring teachers are at a cross section between formal education, the social context and non-formal education.

The relative importance of these diverse formative experiences is not constant over time, but rather it changes as children grown into adolescents and later become adults. In studies on significant life experiences, participants highlight experiencing nature and role models during childhood, teachers and peers during adolescence and participation in activities from environmental organisations and workplace experiences during adulthood (Chawla 1999). Table 12.2 gives an overview of the most formative experience during different periods in life.

Building in possibilities into non-formal education programmes for children to experience such significant life experiences strengthens the formation of environmental identity and could cascade into Environmental Citizenship. Many non-formal environmental education programmes take place in or close to natural areas. Yet being close to nature is insufficient if we have the ambition to facilitate children to form an environmental identity solely based on experiencing nature. Non-formal educators should therefore capitulate on allowing children to play in nature and contribute - at their own level - to the conservation or restoration of nature (e.g. Kellert 2002). Examples of outdoor learning activities and their facilitating role in

Table 12.2 Formative experiences ranked from most to least important at different stages in development

\begin{tabular}{l|l|l}
\hline Childhood & Adolescence & Adulthood \\
\hline Experiences in nature & $\begin{array}{l}\text { Formal } \\
\text { education }\end{array}$ & Organisations \\
\hline Family role models & $\begin{array}{l}\text { Friends and } \\
\text { peers }\end{array}$ & Workplace experiences \\
\hline Formal education & $\begin{array}{l}\text { Social (in) } \\
\text { justice }\end{array}$ & Friends and peers \\
\hline Organisations & Organisations & Books and authors \\
\hline $\begin{array}{l}\text { Negative experiences with nature } \\
\text { (habit loss, pollution) }\end{array}$ & $\begin{array}{l}\text { Negative experiences with nature } \\
\text { (habit loss, pollution) }\end{array}$ \\
\hline Social (in)justice & Philosophy of life \\
\hline
\end{tabular}


the construction of environmental citizenship are described in recent publications such as those produced by Ferreira and Pitarma (2018) from Portugal.

\subsubsection{From Experiencing Nature to Agency for the Environment}

The features of non-formal education allow this system to focus on learning environments, which can be perceived as spaces where children will engage in experiences possibly to be seen as 'ecological identity works' (Thomashow 1995). Being exposed to a wide range of experiences and perspectives, engaging in discussions based on an adapted vocabulary and at an developmentally appropriate level of abstraction, are a crucial elements in developing children's environmental identities. Ideally, the development of an environmental identity should be essentially concerned with an understanding and appreciation of the environment and the significance of the natural order through a dialogue between place and self (Bonnett 2013). Chawla and Flanders-Cushing (2007) go forward and set up a link between environmental identity and Environmental Citizenship, stressing that education provided in a non-formal environment will contribute to environmental identity development, which is necessary to produce both active citizens and embed democratic principles within the education process.

Next to developing an environmental identity, children also need to develop a sense of efficacy for the actions they undertake. Bandura (1997) puts forward that a sense of agency (whether it be to contribute the solving environmental issues or in any other domain) already begins during infancy, in the recognition that actions produce outcomes and that these outcomes can be attributed to a developing identity. This way children discover that they are able to produce interesting and useful effects. Chawla (2009) illustrates that natural environments are filled with opportunities for competence and agency-building opportunities. She describes how natural areas are 'full of materials that enable children to produce pleasurable effects, such as water to splash, mud to meld, branches to swing on, and stick and stones to construct forts and huts' (Chawla 2009, p. 15). Natural places also present plenty of opportunities to experience new levels of agency, and they are usually beyond the adults' direct control. Children learn agency in these rich and stimulating environments, and their learning is not directed by goals set by adults, such as teachers within the formal education system. Such experiences build a child's healthy relationship with nature and therefore make an unmistakeable contribution to the development of Environmental Citizenship. Inspiring examples of educational interventions in the non-formal sphere can be found - for example, - in the New Zealand publication 'Effective approaches to connect children with nature' (Wilson 2011).

Bandura (1997) also describes how children develop a sense of efficacy for their actions through mastery experiences when they attempt to do something that they 
consider significant and when they experience success. This is an essential ingredient for non-formal education programmes to aim to foster Environmental Citizenship in children. Malone (2013) explains how positioning children as active agents of change in non-formal learning programmes (focused on designing a child-friendly neighbourhood) led them to recognise their sense of connectedness and stewardship for the local environment and their sense of responsibility to the planet.

In conclusion, Environmental Citizenship is a highly complex and multifaceted concept that includes knowledge, attitudes, values and actions; children need opportunities to learn and practice these action skills and experience that their actions for the environment can be successful. Non-formal education that facilitates the formation of an environmental identity and that presents children with opportunities to experiences mastery at their developmental level paves the way for them to develop Environmental Citizenship.

Acknowledgements This chapter is based on work from Cost Action ENEC - European Network for Environmental Citizenship (CA16229) supported by COST (European Cooperation in Science and Technology).

\section{References}

Ausubel, D. (1964). The transition from concrete to abstract cognitive functioning: Theoretical issues and implications for education. Journal of Research in Science Teaching, 2(3), 261-266.

Bandura, A. (1997). Self-efficacy. New York: W.H. Freeman.

Barbiero, G., \& Marconato, C. (2016). Biophilia as emotion. Visions for Sustainability, 6, 45-51.

Biesta, G. (2015). Beyond learning. Democratic education for a human future. New York: Routledge.

Boeve-de Pauw, J., Gericke, N., Olsson, D., \& Berglund, T. (2015). The effectiveness of education for sustainable development. Sustainability, 7, 15693-15717.

Boeve-de Pauw, J., Van Hoof, J., \& Van Petegem, P. (2019). Effective field trips in nature: The interplay between novelty and learning. Journal of Biological Education, 53(1), 21-33.

Bonnett, M. (2013). Normalizing catastrophe: Sustainability and scientism. Environmental Education Research, 19, 187-197.

Chawla, L. (1999). Life paths into effective environmental action. The Journal of Environmental Education, 31, 15-26.

Chawla, L. (2009). Growing up green: Becoming an agent of care for the natural world. Journal of Developmental Processes, 4(1), 6-23.

Chawla, L., \& Flanders Cushing, D. (2007). Education for strategic environmental behavior. Environmental Education Research, 13, 437-452.

Cheng, J. C. H., \& Monroe, M. (2012). Connection to nature: Children's affective attitude to nature. Environment and Behavior, 44(1), 31-49.

Cincera, J., Johson, B., \& Kovacikova, S. (2014). Evaluation of a place-based environmental education program: From there to here. Applied Environmental Education \& Communication, 14(3), 178-186.

Clayton, S. (2003). Environmental identity. In S. Clayton \& S. Opotow (Eds.), Identity and the natural environment (pp. 45-65). Cambridge, MA: MIT Press.

Eshach, H. (2007). Bridging in-school and out-of-school learning: Formal, non-formal and informal education. Journal of Science Education and Technology, 16(2), 171-190. 
Ferreira, M. A., \& Pitarma, R. (2018). Outdoor learning activities as facilitators in the construction of environmental citizenship. In N. Llevot-Calvet \& O. Bernad-Cavero (Eds.), Advanced learning and teaching environments. London: Intechopen.

Fordham, P. (1993). Informal, non-formal and formal education programmes. London: YMCA.

Gill, T. (2014). The benefits of children's engagement with nature: A systematic review. Children, Youth and Environments, 24(2), 10-34.

Goldman, D., Pe'er, S., \& Yavetz, B. (2015). Environmental literacy of youth movement members - is environmentalism a component of their social activism? Environmental Education Research, 23(4), 486-514.

Hadjichambis, A., \& Reis, P. (2018). European Network for Environmental Citizenship (ENEC). Impact, 8, 52-54.

Heimlich, J. E. (1993). Nonformal environmental education: Toward a working definition. ERIC Clearinghouse for Science, Mathematics, and Environmental Education, SE 053515.

Kahn, P. H., Jr. (2002). Children's affiliations with nature: Structure, development, and the problem of environmental generational amnesia. In P. H. Kahn Jr. \& S. R. Kellert (Eds.), Children and nature: Psychological, sociocultural, and evolutionary investigations. Cambridge: The MIT Press.

Kellert, S. R. (2002). Experiencing nature: Affective, cognitive and evaluative development in children. In P. H. Kahn \& S. R. Kellert (Eds.), Children and nature: Psychological, sociocultural and evolutionary investigations. Cambridge: MIT Press.

Kellert, S. R. (2005). Building for life: Designing \& understanding the human-nature connection. Washington, DC: Island Press.

Kempton, W., \& Holland. (2003). Identity and sustained environmental practice. In S. Clayton \& S. Opotow (Eds.), Identity and the natural environment (pp. 317-341). Cambridge, MA: MIT Press.

Kimble, G. (2014). Children learning about biodiversity at an environment centre, a museum and at live animal shows. Studies in Educational Evaluation, 41, 48-57.

Levi, D., \& Kocher, S. (1999). Humans valuing nature: Synthesising insights from philosophy, psychology and economics. Environmental Values, 8, 381-401.

Lockhart, A. S. (2016). Non-formal and informal programs and activities that promote acquisition of knowledge and skills in areas of Global Citizenship Education (GCED) and Education for Sustainable Development (ESD). Paper commissioned for the Global education monitoring report 2016, Education for people and planet: Creating sustainable futures for all, UNESCO, ED/GEMR/MRT/2016/PA/22.

Malone, K. (2013). "The future lies in our hands": Children as researchers and environmental change agents in designing a child-friendly neighbourhood. Local Environment, 18, 372-395.

Manoli, C. C., Johnson, B., Hadjichambis, A., Hadjichambi, D., Georgiou, Y., \& Ioannou, H. (2014). Evaluating the impact of the earthkeepers earth education program on children's ecological understandings, values and attitudes, and behaviour in Cyprus. Studies in Educational Evaluation, 41, 29-37.

Norland, N. (2005). The nuances of being "non": Evaluating non-formal education programs and settings. New Directions in Evaluation, 108, 5-12.

Romi, S., \& Schmida, M. (2008). Non formal education: A major educational force in the postmodern era. Cambridge Journal of Education, 39(2), 257-273.

Ruiz-Mallen, I., Barraza, L., Bodenhorn, B., \& Reyes-García, V. (2009). Evaluating the impact of an environmental education programme: An empirical study in Mexico. Environmental Education Research, 15(3), 371-387.

Ryan, R., \& Deci, E. (2003). On assimilating identities to the self. In M. Leary \& J. Tangney (Eds.), Handbook of self and identity (pp. 253-272). New York: Guilford.

Schultz, P. W. (2000). Empathizing with nature: The effects of perspective taking on concern for environmental education. Journal of Social Issues, 56(3), 391-406.

Tanner, T. (1980). Significant life experiences: A new research area in environmental education. The Journal of Environmental Education, 11(4), 20-24. 
Tesch, D., \& Kempton, W. (2004). Who is an environmentalist? The polysemy of environmentalist terms and correlated environmental actions. Journal of Ecological Anthropology, 8, 67-83.

Thomashow, M. (1995). Ecological identity. Cambridge, MA: MIT Press.

UNICEF/United Nations Centre for Human Rights. (1990). Convention on the rights of the child: Briefing kit. Geneva: UN Centre for Human Rights/UNICEF.

Van Martre, S., \& Johnson, B. (1988). Earthkeepers - Four keys for helping young people live in harmony with the earth. Cedar Grove/Greenville: Institute for Earth Education.

White, R., \& Stoecklin, V. (2008). Nurturing children's biophilia: Developmentally appropriate environmental education for young children. White Hutchinson Leisure \& Learning Group.

Williams, C. C., \& Chawla, L. (2016). Environmental identity formation in nonformal environmental education programs. Environmental Education Research, 22(7), 978-1001.

Wilson, R. (1993). Fostering a sense of wonder during the early childhood years. Columbus: Greyden.

Wilson, C. (2011). Effective approaches to connect children with nature. Principles for effectively engaging children and young children with nature. New Zealand Department of Conservation: Wellington.

Younnis, J. (2011). Civic education: What schools can do to encourage civic identity and action. Applied Developmental Science, 15(2), 98-103.

Open Access This chapter is licensed under the terms of the Creative Commons Attribution 4.0 International License (http://creativecommons.org/licenses/by/4.0/), which permits use, sharing, adaptation, distribution and reproduction in any medium or format, as long as you give appropriate credit to the original author(s) and the source, provide a link to the Creative Commons license and indicate if changes were made.

The images or other third party material in this chapter are included in the chapter's Creative Commons license, unless indicated otherwise in a credit line to the material. If material is not included in the chapter's Creative Commons license and your intended use is not permitted by statutory regulation or exceeds the permitted use, you will need to obtain permission directly from the copyright holder.

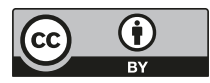

